PART 2

Entitlement 
Jesper Bjarnesen - 9789004356368

Downloaded from Brill.com04/26/2023 11:37:59AM via free access 


\title{
The Politics of Inclusion and Exclusion in Urban Burkina Faso
}

\author{
Jesper Bjarnesen
}

\section{Introduction}

The Ivorian civil war carried significant political and economic consequences for the whole West African subregion for most of the first decade of the twentyfirst century. Burkina Faso has historically provided a significant proportion of the labour force for Côte d'Ivoire's plantation economy and Burkinabe labour migrants and their descendants in Côte d'Ivoire were at the heart of the political crisis that lead to armed conflict, causing more than 500.00o Burkinabe migrants to leave Côte d'Ivoire because of persecution (McGovern 2011). For second-generation immigrants to Côte d'Ivoire, the political rhetoric of "sending the strangers home" rang as false as it does in many other contexts around the world, including northern Europe's increasing hostility towards immigrants and their children. Forced to leave Côte d'Ivoire because of violent persecution, the children of labour migrants of Burkinabe descent arrived to their parents' country of origin only to encounter a new set of exclusionary discourses, labelling them as 'Ivorian'; as being betwixt and between categories of national belonging; or, simply, as "Diaspo".

In response to such hostility from their new neighbours in Burkina Faso, young migrants employed a range of strategies to cope with their social exclusion. For example, the involvement of young migrants in the 2010 presidential elections testifies to the resourcefulness and effectiveness of youths in negotiating the politics of inclusion and exclusion. This chapter analyses some of these strategies and argues, firstly, that the mobilization of a collective response to the social exclusion of young migrants in Bobo-Dioulasso was premised on that very exclusion as a source of identity among migrants - who gradually came to perceive of themselves as a collective. Secondly, that this mobilization of "Diaspo" identity served to simultaneously provide young migrants with a sense of purpose and belonging, and to transform a diverse group of young self-settled refugees into a socio-political force to be reckoned with in Bobo-Dioulasso. Thirdly, that "Diaspo" youth identity was gradually transformed from a social 
stigma into a symbol of cosmopolitanism that leant itself perfectly to the local and national political elites, eager to replicate global images of participatory democracy and youth participation. Finally, the chapter argues that the politics of inclusion and exclusion more generally may be understood as fundamental to dynamics of identity formation, in which young adults are particularly liable to be both the targets of stigmatization and the principal actors in articulating counter discourses and mobilizing against their social exclusion.

The concept of the politics of inclusion and exclusion is thereby evoked to characterize the paradoxical social dynamics by which exclusionary practices against a social category also imply the reproduction and partial inclusion of that category into the social fabric; a 'complex dialectic of inclusion and exclusion' (Hage 1998, 135). In the case of the Diaspos in Bobo-Dioulasso, this conceptualization is illustrated both in the ways in which the derogatory category of Diaspo provided migrant youths with a recognisable social brand (Bjarnesen 2014), and at the same time enabled their collective mobilization as Diaspo; a social role that was ascribed to them for the purposes of social exclusion but came to serve as a significant source of self-identification and sense of worth.

The chapter is based primarily on ethnographic fieldwork carried out in Bobo-Dioulasso during January-December 2010, which combined formal interviews, focus groups, and extended participant observation to study the informal dynamics of integration and exclusion of involuntary return migrants from Côte d'Ivoire.

\section{Becoming Diaspo in Bobo-Dioulasso}

In Bobo-Dioulasso, Burkina Faso's second-largest city, young adult refugees from Côte d'Ivoire were received with marked ambivalence from both local authorities and their new neighbours. On the one hand, labour migration from Burkina Faso to Côte d'Ivoire has been a key livelihood option as well as a socio-cultural rite of passage for successive generations of Burkinabe men and (increasingly) women since the colonial period (Cordell, Gregory and Piché 1996; Zongo 201ob). In this sense, second-generation immigrants to Côte d'Ivoire were seen as representatives of the dreams of many young aspiring migrants in Burkina Faso and their "Ivorian" dialect, dress, and behaviour were seen as expressions of the cosmopolitan modernity associated with Côte d'Ivoire in general and its financial centre, Abidjan, in particular (Bjarnesen 2014). On the other hand, however, the competition over livelihood and living space in the city prompted considerable resentment towards the influx of large numbers of 
self-settled refugees from the Ivorian civil war (Bjarnesen 2015). In this sense, the young migrants were taunted for being out-of-place: neither truly Ivorian, nor truly Burkinabe. These sentiments were at the heart of a social stigma that was ascribed to the new arrivals to the city: "Diaspo".

The term Diaspo was originally applied to a particular group of university students in Burkina Faso's capital, Ouagadougou, in the 1980s. Burkinabe labour migrants in Côte d'Ivoire often chose to send their children back to Burkina Faso to pursue higher education due to the instable political situation in Côte d'Ivoire which led to continuous strikes at the university and "blank years" when students at Ivorian universities were unable to complete their exams (Zongo 2010a). These university students became known as "the children of the Burkinabe diaspora in Côte d'Ivoire" or, in short, the "Diaspos". In the context of the Ivorian civil war, the term "Diaspo" took on a different meaning, as larger groups of young adult children of Burkinabe labour migrants in Côte d'Ivoire arrived in their parents' country of origin, often for the first time. These youths were a much more heterogeneous group but were nevertheless ascribed with the combination of privilege and arrogance that had been associated with the "Ivorian" university students in Ouagadougou a generation earlier.

The story of Djibril's arrival in Bobo-Dioulasso and his experiences of facing and coping with social exclusion are illustrative of how one might come to perceive oneself as Diaspo. Born in Côte d'Ivoire's south-western cocoa-producing region, he went to school in the town of San Pedro until the tensions between migrant workers and Ivorian land owners prompted his parents to consider a new life in Burkina Faso. After the Tabou massacres in 1999, in which more than 100 Burkinabe plantation workers were killed (Le Pape and Vidal 2002), Djibril's parents became increasingly aware of the threat they were facing as Burkinabe immigrants in Côte d'Ivoire. In early 2002 they sent Djibril, then sixteen years old, to live with an uncle to continue his studies in Bobo-Dioulasso. Djibril had been too young to understand the hostilities taking place in Côte d'Ivoire, he said, but he still remembered the day he realized that he was not Ivorian like his friends:

I remember ... the first time I understood that I was not Ivorian JB: Aha?

Yes, because we were in Côte d'Ivoire, we walked with ... well, that is with "the Ivorians", as if I knew that they were "Ivorians", me [I didn't know]. We walked together, we did everything together, having fun. One day in the sixth grade $\left[\mathrm{CM}_{2}\right]$ the teacher decided to have the strangers stand up

JB: They stand up in class ... Aha. 
That they stand up in class, exactly, because it was as if he wanted ... to count the number of strangers that were in the class. Well, me I was still seated because I didn't even know where my parents came from - in the sixth grade, eh! - I didn't even know where he is going with that question. I was still seated. He took the sheet, he says, "but Ouattara, get up!" Well, I stood up. It was when I came home, I say "but what is all that about?" They explained it to me. They said ... that's when they began to make me understand that me, my country, it's Burkina Faso.

Djibril felt naïve that he had not understood his origins sooner and realized that he was different from his classmates. In a scene that could have been taken from a story set in the Germany of the 1930s or Rwanda in the early 1990s, his teacher was the first to let him know that his family name gave his origins away and that he was a stranger in Côte d'Ivoire. This would have been in 1997-98, at a time when Henri Konan Bédié was President of the Republic and had introduced his concept of ivoirité into the national political debate which drew new boundaries of Ivorian citizenship based on the elusive idea of autochthony (Dunn 2009; Geschiere 2009; Dembélé 2002). A few years later, Djibril left Côte d'Ivoire with his older brother who was already studying medicine at the university in Bobo-Dioulasso. Djibril initially lived under the patronage of his paternal uncle until the arrival of his father, in 2005, and during that time he had continued his studies until the ninth grade but he had failed his final exams and been unable to acquire a diploma. He dropped out of school in 2007. Since then he had struggled to find work, in his own opinion largely due to the stigmatization he faced, having grown up in Côte d'Ivoire:

I can say that in that sense even, there were ... big persons ... big persons, you could say the authorities here even, who ... really ... who didn't like us, eh.

JB: Really?

Yes, when you go like that to establish ... for the establishment of your [ID] paper, a paper like that, "Ah it's another Ivorian, there", that, "it's you, you've come to wreck our country!" In fact, they, to them, we have come to wreck their country, but that's not it. There were even protests where they managed to ... the President [Compaoré] - excuse me - himself he went out and said that if today the country is going astray, it's because of the arrival of these youths from Côte d'Ivoire!

Djibril believed that it was this kind of prejudice against migrants arriving from Côte d'Ivoire that had prevented him from finding work. Another 
underlying difficulty would obviously be the lack of personal connections in the city, or elsewhere in Burkina Faso, which was a disadvantage in a society where much recruitment into both the public sector and other jobs seemed to rely heavily on knowing someone in an advantageous position. Similar experiences were expressed by other young people who had come to Burkina Faso for the first time in their youth. Their clothes, linguistic styles, and mannerisms that were associated with Côte d'Ivoire in general, and $a b i$ djanais youth culture in particular, made these young men and women stand out - something that made it easier to make both friends and enemies in the neighbourhood.

\section{Fighting for Integration}

Djibril, perhaps, emphasized discursive persecution over his lack of personal connections because he had been involved with several attempts to mobilize young "Ivorians" against their stigmatization in order to negotiate access to formal employment as a disadvantaged minority. He was currently involved in a new association, after the previous group disintegrated when its president was named president of the national youth council at the provincial level. The new association was called "Diaspora et développement", Diaspora and Development, referring to the most persistent label that Djibril and his friends had been given in Burkina:

They call us "the Diaspo". Well, the expression is badly chosen, since a Diaspo is someone who lives in Côte d'Ivoire ... it's a Burkinabe who lives in Côte d'Ivoire who is the Diaspo, you know, "the diaspora". There. But us, we are not Diaspos.

Faced with the derogatory term Diaspo, Djibril was not alone in remarking that the idea of 'diaspora' was difficult to reconcile with his own situation, since he was now living in the country to which his citizenship was ascribed; Burkina Faso. But, as Zongo notes, the term's origins in the circles of university students in Ouagadougou suggest that the term "Diaspo" was coined as an abbreviation of 'children of or from the diaspora' (Zongo 2010a:35, my translation), referring to the above-mentioned tendency for Burkinabe migrants in Côte d'Ivoire of sending their children to Burkina Faso to continue their education. To Djibril, however, being labelled as Diaspo upon his arrival to the country that he had painfully learned, while in Côte d'Ivoire, was his true origin was not only unjust but also semantically nonsensical (Bjarnesen 2013). 
The former president of the association was a friend of Djibril's and he had told Djibril that the only way to get a job was to mobilize collectively, as Diaspos, that is to use that label as a rallying point in order to reach local politicians and attempt to negotiate access to public employment. More generally, the association had become a vehicle for reinterpreting the term "Diaspo" by evoking, on the one hand, the initiative and resourcefulness of young people like Djibril and, on the other, to exploit the positive connotations of the Burkinabe diaspora in Côte d'Ivoire who, as Djibril was quick to emphasize, contributed significantly to the Burkinabe economy through remittances although that influence was rarely acknowledged.

So far, the organization was in its embryonic stage, with Djibril and fourteen other volunteers coordinating meetings and collecting membership fees and approximately three hundred paying members across the city but to Djibril it was one among several ways of trying to turn his labelling into an advantage. I asked him why he was so committed to the idea of changing the connotation of the word "Diaspo":

I fight to integrate myself, that is to say, I ... integrate by force. Right. I integrate by force because I acknowledge now that "home", it's here. I have become aware, since I was young. I see that "home" is here.

Djibril explained that he had decided to show "the autochtone", as he put it, that he was more Burkinabe than "him" and to learn everything about his country to prove his commitment to Burkina Faso. He said that "Diaspora et développement" was based on the same idea: of showing their critics that they were a positive force in society, to be acknowledged as truly belonging: 'So, it will be another shot for us to show people here that we are truly [brief laugh] the sons of the country, you know'.

Djibril's experiences of being labelled as a stranger once more, having already left Côte d'Ivoire with the label "Burkinabe" ascribed to him, were shared by other Diaspos in Bobo-Dioulasso. Although the Burkinabe diaspora in Côte d'Ivoire has always been valued for its contribution to the Burkinabe economy through remittances and investments, the arrival of large numbers of displaced migrants during the Ivorian crisis changed the view that nonmigrant Burkinabes held of the diaspora and brought veiled resentments out into public discourse. In this re-evaluation of the role of the Burkinabe diaspora in Côte d'Ivoire, the Diaspo youths were seen as the personification of the problem - of Burkinabe migrants who had abandoned their Burkinabe origins and integrated into Ivorian society, to the extent that their speech, dress, behaviour, and social values were seen as alienated and inappropriate by nonmigrant Burkinabes. 


\section{Performing Subservient Youth}

Dramane, Djibril, and Youssouf were close friends. They would usually hang out in front of the house of another Diaspo friend, Cristophe, under the shade of a mango tree in the corner of a small quadratic open space in the neighbourhood of Sarfalao. One Sunday afternoon, as Djibril was taking his chance against the undefeated scrabble champion of the day and Dramane was practicing lyrics for an upcoming musical performance with Youssouf, the drowsy atmosphere was interrupted when a large white car, known locally as "quatrequatre", referring to the " $4 \times 4$ " four wheel drive mark on the side of such vehicles, pulled up in front of the mango tree.

A youthful looking man in his early fifties emerged and greeted the young men, who dutifully shook hands and sat up from their cosy positions. His driver also greeted us while his boss proceeded to inspect the open space in front of us, which was being cleared for shrubs at the end of the rainy season. He was involved in a resident initiative to improve the roads and rain dikes of that part of the neighbourhood and had come to meet with Cristophe's uncle, the owner of the courtyard that served as a Diaspo meeting point. After his casual inspection, the man from the car returned to our circle and asked if tea was ready. Youssouf, who had been chatting lazily about the shrub-clearing issue with the others changed his voice and posture in a blink, from the confident, talkative, and smiling way I had come to know into a shrugging, subdued, and humble demeanour that made him almost unrecognizable. He politely replied that the tea was not ready yet. The man with the car was smiling and unimposing in his attitude, which made the contrast with Youssouf's servility all the more striking. Some "big men" (Utas 2012) I met in Bobo-Dioulasso would take on a very imposing attitude towards young men, but this man's authority shone through his jovial manner, reinforced by the reactions of the youths. The man gave Youssouf 1,00o fCFA and said that he had hoped that a contribution would have earned him a taste but Youssouf repeated that he was sorry to say that he might have to wait a while. The man then asked whether Youssouf was a Diaspo. Youssouf confirmed that he was born and raised in Côte d'Ivoire. The man replied that he could tell from his demeanour that Youssouf was a Diaspo - his appearance, his speech.

The second the man turned around, Youssouf's attitude changed, and he told me, "Let's go!" which I thought meant that he wanted us to follow the man towards his car. The others laughed and I understood his joke that he and I should make off with the cash. What I found remarkable about this episode, and the countless similar ones I have witnessed, was how the role of subservient junior to the authoritative (however understated in this particular instance) senior was, first of all, assumed and dropped in the blink of an eye 
and, secondly, how unremarkable this spectacle was to the group of youths who were witnessing the transformations with me.

As numerous studies of African youth have showed in the past ten years (e.g. Abbink and van Kessel 2005; Abdullah 1998; Argenti 2006; Bucholtz 2002; Cruise O'Brien 1996; Durham 2000; Vigh 2006b), the hierarchical position of junior in relation to someone senior epitomizes the notion of youth but this structural relationship does not determine how these roles are played, or used, by individual actors. In this trivial episode, Youssouf embraced the role of a subservient youth, thereby providing the group with a little extra money for tea and, potentially, a positive relationship with a member of a local social network that might be nurtured into a more binding alliance. This choice, and shifting, of roles reflecting different aspects of youth should not be seen simply as fake or manipulative charades. In Goffman's influential terminology, a social performance may be understood as the individual's effort to fit into an already established social role or category. Performativity may tend to be misunderstood analytically as a more artificial, or insincere, form of social practice, but to Goffman, seeing social practice as a social performance does not concern, conceptually, the sincerity of the performer but rather the premise that ' $\mathrm{i}] \mathrm{f}$ a performance is to come off, the witnesses by and large must be able to believe that the performers are sincere. This is the structural place of sincerity in the drama of events' (Goffman 1959:77; see also Argenti 2007:11). Sasha Newell's analysis of 'the modernity bluff' in Abidjan also points out that the performance of established social roles, even when performed with an exaggerated theatricality, tends to reinforce 'ideas of authenticity and essence rather than destabilizing them' (Newell 2012:140), which makes the question of the performer's sincerity less important than the reproductive effects of the performance itself. This last point is important for understanding the structural implications of the collective mobilization of Diaspo youths, as I will argue in this chapter's conclusion.

\section{Cheering for a Living}

On a Sunday in August in 2010, Dramane and his friends were summoned to take part in the inaugural ceremony of the newly appointed President of the Regional Youth Council of Hauts-Bassins; the former president of Diaspora et developpement who had used his position to gain access to the city's governing party (CDP) representatives. Dramane circulated the message to the group and their tag-along ethnographer on Saturday evening and the following day, we met under the mango tree at Cristophe's place as instructed. We were all 
given a t-shirt in red, green, or yellow with the print 'Regional Youth Council of Hauts-Bassins. A Structure in the Service of the Youth', to wear during the ceremony.

We met the others in front of the imposing Catholic church in one of the city's upper class neighbourhood, in front of which a row of shiny land cruisers were parked. Inside the imperious meeting hall of the church, an assembly similar to the one unfolding was being displayed on film on a large screen to the right of a podium with a line of tables with name cards and small bottles of water. We waited outside in our colourful t-shirts and when someone passed us going to or leaving the meeting hall, one of the Diaspos would imitate the person's walk or make faces behind their back to the applause of the others. A tall man in a dark suit, who I learned was the President of the National Youth Council, came over and shook hands with Dramane, whom he knew by name and seemed to like. Dramane made a few jokes about his fancy suit, speaking with plenty of Ivorian nouchi slang and attitude but slightly more polite than he would to the rest of us "youths". At 33 I was probably among the oldest in the group but I would estimate the average to be around 27 in our "youth group". But on this occasion, despite their age, the Diaspo youths played their part well. When the inauguration ceremony began, we were placed at the back wall of the meeting hall and given a streamer with the same text as our t-shirts. Inbetween speeches, our group would sing celebratory songs to the speaker and we would lead the applause and cheering during and after each speech. The event's guest of honour was the Minister for Youth and Employment and other prominent guests included the Minister of Agriculture and the National Youth President that Dramane had met with before the ceremony.

During the first speech, Dramane and Youssouf whispered the lyrics to a song they had apparently improvised for the occasion to the rest of us. By the fourth interlude, the group had worked out the song quite well and after the final speech, the TV crew from Rтв approached us through the centre aisle from the podium and the Diaspo youths were given a moment in the spotlight while the crowd applauded.

What this description shows is first of all how the role of supporters to the regional youth council provided an entrance into the sphere of regional and national politics that many unemployed youths would never dream of. Performing the role of youthful backing singers is obviously not an expressway to fame and fortune but, at least to Dramane in this description, the connections to important allies in the political elite were maintained through these events. A month later, Djibril and Dramane were selected as volunteers for the Ministry of Employment and Youth's regional office in Bobo-Dioulasso during the preparations of the celebration of Burkina Faso's 5oth Anniversary 
of national independence in December 2010 in competition with hundreds of other applicants, perhaps not exclusively by way of their performance at the inauguration but no doubt because of their ability to contribute to such events in a positive and appropriate manner.

Rather than being subdued youths, the role taken by the Diaspos at the inauguration was one that fit better with the pretentions of the Ministry and the Regional Youth Council where the youth represent the future of the nation, and an important segment of the electorate, and where the cheering and colourful group at the back of the meeting hall represents the promise of the youth of the entire region. The irony, of course, is that the vast majority of this particular group consisted of youths who had grown up in Côte d'Ivoire and who were struggling for recognition vis-à-vis their peers in the city. But the extrovert and jovial attitude of Dramane and his friends fit in perfectly with this event and Dramane's ability to play the role of the trickster by joking around with the National Youth President might have served him better than the subservient attitude that Youssouf displayed towards the "big man" under the mango tree. On our way home, Djibril explained that in the circles of the political elite it was no use to ask for help or try to be humble: these guys faced such behaviour from all the youths of their social networks on a daily basis and Djibril knew that it drove them crazy.

Performing youthfulness, even in your late twenties or early thirties, might be a way of combining the best of a more cosmopolitan idea about youth as the nation's future with the best of the persisting gerontocratic hierarchies where those youths most able to assert themselves gain access to higher positions within the structure while others remain stuck in youth as employment opportunities and access to higher education continue to recede (Mbembe 1985). In a context of high unemployment rates and restricted livelihood opportunities, mobilizing as Diaspos turned out to provide some youths with access to parts of the local and regional political elite though their ability to perform the role of vibrant and active youths, representing the spirit of the regional and national youth councils and the political slogans about the country's future. In this way, Diaspo youth culture served as a social asset that provided Diaspo youths with access to elite networks. Paradoxically, performing youth at political rallies showed a potential way out of the social moratorium of youth which, Henrik Vigh argues, characterizes the social position of youth in a context where persistent economic decline and 'generationally asymmetric control over access to resources ... greatly reduce [young people's] space of possibilities' (Vigh 2006a:96). Performing Diaspo youth culture in the service of the local political elite, in other words, was a way for the Diaspos to negotiate access 
to networks of privilege that might serve as a path away from the social position of youth, towards social adulthood (Barrett 2004).

\section{Progression within and Despite Networks of Access}

I once asked Patrice how he would describe the difference between himself and someone like Djibril. He asked me to elaborate and I said that on the one hand they were approximately the same age, they were both born and raised in Côte d'Ivoire and they were both called "Diaspo" in Bobo-Dioulasso. On the other hand, they spoke differently and behaved differently - Djibril confirming the Diaspo stereotype to a much larger extent, while Patrice was less outspoken and dressed more like his Burkinabe neighbours. Patrice said that the difference was that Djibril was always in the Diaspo "system": he always behaved as a Diaspo and hung out with other Diaspos. Patrice used to be more like that when he first arrived in Burkina Faso. He had used more nouchi vocabulary and dressed in fashionable clothes without caring what other people thought: 'The Diaspos don't care', he said repeatedly. Now Patrice lived in a part of the neighbourhood where many of his neighbours were Burkinabe. He had also aged, and matured, and was responsible for his girlfriend and their daughter. He could no longer be as carefree and he was more concerned with fitting in. Patrice's new priorities did not go unnoticed. In a focus group with six young Diaspo women, my question about what characterizes a Diaspo young man evolved into a longer discussion in which Patrice was taken as a counter point to 'typical Diaspo behaviour'. He was described by the focus group participants as responsible and mature, unlike many of his agemates who still behaved like young boys by trying to seduce girls just for the fun of it. To the Diaspo women in this discussion, being a Diaspo youth was fine for a certain time in your life but inappropriate for someone with children and more responsibility.

Patrice experienced the tension between his earlier and current priorities in his relationship with his best friend Julien these days. They were the same age, shared the same background, and were practically neighbours. But Julien acted much more as a Diaspo than him - he was always in the system. They would talk about that when they went out. Julien would even tell Patrice to slow down, saying that he could no longer be as Diaspo as the others, now that he had a wife and kid to tend to. There were other, slightly older, guys that Patrice knew in the neighbourhood who had changed in a similar way. Those were the people Patrice related to these days and wanted to emulate. 
In this way, the desire to distance oneself from the youthful category of Diaspo may not only be related to a desire to climb the ladder in one particular form of hierarchy. Performing the role of subservient youth may follow someone until death, since that position is relational to a particular position as senior (Durham 2004). But the youthfulness of Djibril and his friends at the inauguration has a social due date. As parents, both men and women may feel the incentive to relate more to other social roles, as Patrice did to his more mature male neighbours. Being in your early thirties, in and of itself, says very little about the appropriateness of embracing the role of cheering for the elite in the hope of eventually joining them. More than age, other factors such as becoming a parent, a head of household, or being steadily employed may be much more forceful in marking the gradual transition towards a new social role (Johnson-Hanks 2002). For the Diaspos, such roles would, once again, have to be invented as they went along.

\section{Conclusion}

From its origins in the university circles in Ouagadougou in the late 1980s, the term Diaspo became associated with migrant families returning in the context of the Ivorian crisis, connoting the two-fold exclusion of young secondgeneration migrants who were neither Ivorian - given their parents' origins nor Burkinabe, due to their upbringing in Côte d'Ivoire. The chapter considered two different expressions of the social performance of youth in this regard. On the one hand, political rallies and campaigns set the stage for the Diaspos to perform the role of an active and politically engaged national youth. But, on the other hand, in the practice of everyday life, the role of youth might rely more on cultural idioms of generational hierarchy. In these contexts, performing youth implied acting as subservient and respectful towards seniors - a performance that went counter to the general stereotype of the Diaspo as outspoken and arrogant.

In their navigation of the social position of youth, the Diaspos relied not only on global discourses of youth as the future of the nation but also on the very restrictiveness of local social hierarchies to which it might seem to stand in opposition. Put differently, the combination of a cultural platform that encouraged the performance of youth culture with a social hierarchy premised on seniority provided the Diaspos with a room for manoeuvre that would not otherwise have been available. This image of youth culture departs considerably from the Birmingham School's view of youth culture as resistance (Hall and Jefferson 1976), and later works on youth culture as a vibrant form 
of self-expression and liberation from societal norms (Maira and Soep 2004; Amit-Talai and Wulff 1995) and emphasizes the interplay between social hierarchies and individual agency through which youth may be understood simultaneously as an expression of cultural identity and social positioning, of both being and becoming (Christiansen, Utas and Vigh 2006).

To the Diaspos, the threat of being stuck in the social moratorium of youth persisted but some youths were negotiating access to social progression through networks of privilege at the expense of others. Negotiating social adulthood in this way designates a socially conservative practice that inscribes the image of an active and cheering youth into established social hierarchies. This observation warns against an overly romantic view of youth agency as implying a revolutionary potential for social change. As Deborah Durham argues from her ethnography of Herero youth associations in Botswana:

Youth is not a period of liberation from a home society or cultural traditions, and the motif of development that youth engenders is not a linear move away from the past or from home ... [T] heir agency, or their ability to shape the culture and social relations around them, rests more in their ability to vest [their innovations] in relationalities, which they are only beginning to wield effectively in their later youth years.

DURHAM 2008, 176

While it may be tempting to inscribe the inconspicuous processes of assimilation that Patrice was engaged in, despite his Ivorian upbringing, as representing the more conservative path towards social maturity and pose the performance of Diaspo youth culture as a contrasting example of innovative and independent agents, challenging the established norms of appropriate behaviour, it may be more useful to appreciate both the resourcefulness and independent agency involved in the former, and the conservative ambitions of the latter. The social position of youth implies that young people direct their efforts towards expanding their social networks and accumulating social recognition by all possible means, leading some to evoke their youthfulness in a context where such a social role is perceived as an asset and others to emphasize their sense of responsibility and moderation to a different audience. The public performance of Diaspo youth culture, in this way, may be seen as one among several strategies in the pursuit of social recognition and access to networks of privilege.

This understanding of collective mobilization approaches political involvement as a form of recruitment, rather than an expression of ideological affiliation or social critique. As studies of combatant recruitment have convincingly 
shown, participation in armed conflict may often be understood as a livelihood strategy or a quest for social mobility and worth (Bjarnesen 2016; Christensen and Utas 2008; Vigh 2006a). However, although the collective mobilization of Diaspo youths has been analysed as a socially conservative, or affirmative, livelihood strategy, the politics of exclusion and inclusion also warrant a critical attention to potential uses of such groups. In Burkina Faso, the reign of president Blaise Compaoré came to an abrupt end in late October 2014 and the ongoing restructuring of the national political elite will continue to have repercussions for the local networks that Djibril and his friends have been seeking to join. The Diaspos' service to the president during the 2010 electoral campaign had little to do with political ideology or allegiance and their future connections and recruitment as supporters to local elites will probably depend more on available opportunities than on allegiance to particular influential individuals or groups. This also means that in the case of a militarization of the political competition in Burkina Faso post-Compaoré, the step from cheering at rallies to participating in organized violence may be shorter than one might expect. In a context where social mobility to a large extent depends upon the exclusion of the majority of young people from access to the privileges of the few, youth is a social category that many people will do what it takes to escape.

\section{References}

Abbink, Jon, and Ineke van Kessel, eds. 2005. Vanguard or Vandals. Youth, Politics and Conflict in Africa Edited by P. Konings, P. Mathieu, A. Olukoshi, D. Posel, and R. Watson. Vol. 4, African Dynamics. Leiden: Brill.

Abdullah, Ibrahim. 1998. "Bush path to destruction: the origin and character of the Revolutionary United Front/Sierra Leone”. The Journal of Modern African Studies 36 (2): 203-235.

Amit-Talai, Vered, and Helena Wulff, eds. 1995. Youth Cultures. A Cross-Cultural Perspective. London: Routledge.

Argenti, Nicolas. 2006. "Remembering the Future: Slavery, Youth and Masking in the Cameroon Grassfields". Social Anthropology 14 (1): 49-69.

Argenti, Nicolas. 2007. The Intestines of the State. Youth, Violence, and Belated Histories in the Cameroon Grassfields. Chicago \& London: The Universtiy of Chicago Press.

Barrett, Michael. 2004. "Paths to Adulthood. Freedom, Belonging and Temporalities in Mbunda Biographies from Western Zambia." PhD Diss., Uppsala University, Uppsala. 
Bjarnesen, Jesper. 2013. Diaspora at Home? Wartime Mobilities in the Burkina Faso-Côte d'voire Transnational Space. Uppsala: Acta Universitatis Upsalienses.

Bjarnesen, Jesper. 2014. "Social Branding in Urban Burkina Faso." Nordic Journal of African Studies 23: 331-343.

Bjarnesen, Jesper. 2015. "The Ambivalence of Neighbourhood in Urban Burkina Faso." Anthropology Southern Africa 38 (3-4): 331-343.

Bjarnesen, Jesper. 2016. "Between Labor Migration and Forced Displacement: Wartime Mobilities in the Burkina Faso-Côte d'Ivoire Transnational Space." Conflict \& Society 2: $5^{2-67}$.

Bucholtz, M. 2002. "Youth and Cultural Practice". Annual Review of Anthropology 31: 525-552.

Christensen, Maya Mynster, and Mats Utas. 2008. "Mercenaries of democracy: The 'Politricks' of remobilized combatants in the 2007 general elections, Sierra Leone". African Affairs (London) 107 (429): 515-539.

Christiansen, Catrine, Mats Utas, and Henrik E. Vigh, eds. 20o6. Navigating Youth Generating Adulthood. Social Becoming in an African Context. Uppsala: Nordic Africa Institute.

Cordell, Dennis D., Gregory Joel W., and Piché Victor. 1996. Hoe and Wage. A Social History of a Circular Migration System in West Africa, African modernization and development series. Boulder CO: Westview Press.

Cruise O'Brien, Donal B. 1996. "A Lost Generation? Youth Identity and State Decay in West Africa." In Postcolonial Identities in Africa, edited by R. Werbner and T. Ranger, 55-74. London \& New Jersey: Zed Books.

Dembélé, Ousmane. 2002. "La construction économique et politique de la catégorie 'étranger' en Côte d'Ivoire”. In Côte d'Ivoire. L'année terrible 1999-20oo, edited by M. Le Pape and C. Vidal, 123-171. Paris: Karthala.

Dunn, Kevin C. 2009. “'Sons of the Soil' and Contemporary State Making: Autochthony, Uncertainty and Political Violence in Africa". Third World Quarterly 30 (1): 113-127.

Durham, Deborah. 2000. "Youth and the Social Imagination in Africa: Introduction to parts 1 and 2". Anthropological Quarterly 73 (3): 113-120.

Durham, Deborah. 2004. "Disappearing Youth: Youth as Social Shifter in Botswana". American Ethnologist 31 (4): 589-605.

Durham, Deborah. 2008. "Apathy and Agency: The Romance of Agency and Youth in Botswana." In Figuring the Future. Globalization and the Temporalities of Children and Youth, edited by D. Durham and J. Cole, 151-178. SAR Press.

Geschiere, Peter. 2009. The Perils of Belonging. Autochthony, Citizenship, and Exclusion in Africa and Europe. Chicago: University of Chicago Press.

Goffman, Erving. 1959. The Presentation of Self in Everyday Life. London: Penguin Books Ltd. 
Hage, Ghassan. 1998. White Nation. Fantasies of White Supremacy in a Multicultural Society. London \& New York: Routledge.

Hall, Stuart, and Tony Jefferson. 1976. Resistance through Rituals. Youth Subcultures in Post-War Britain. London: Hutchinson.

Johnson-Hanks, Jennifer. 2002. "On the Limits of Life Stages in Ethnography: Toward a Theory of Vital Conjunctures". American Anthropologist 104 (3): 865-880.

Le Pape, Marc, and Claudine Vidal, eds. 2002. Côte d'Ivoire. L'année terrible 1999-20oo. Paris: Karthala.

Maira, S., and E. Soep, eds. 2004. Youthscapes: The Popular, the National, the Global. Philadelphia: University of Pennsylvania Press.

Mbembe, Achille. 1985. Les jeunes et l'ordre politique en Afrique Noire, Logiques Sociales. Paris: L'harmattan.

McGovern, Mike. 2011. Making War in Côte d'Ivoire. London: C. Hurst.

Newell, Sasha. 2012. The Modernity Bluff. Crime, Consumption, and Citizenship in Côte d'Ivoire. Chicago \& London: The University of Chicago Press.

Utas, Mats. 2012. African Conflicts and Informal Power. Big Men and Networks, Africa Now. London \& Uppsala: Zed Books \& Nordiska Afrikainstitutet.

Vigh, Henrik E. 2006a. Navigating Terrains of War. Youth and Soldiering in Guinea-Bissau. New York \& Oxford: Berghahn Books.

Vigh, Henrik E. 2006b. "Social Death and Violent Life Chances". In Navigating Youth - Generating Adulthood. Social Becoming in an African Context, edited by C. Christiansen, M. Utas and H.E. Vigh, 31-6o. Uppsala: Nordic Africa Insitute.

Zongo, Mahamadou. 2010a. "Migration, diaspora et développement au Burkina Faso." In Les enjeux autour de la diaspora burkinabè. Burkinabè à l'étranger, étrangers au Burkina Faso, edited by M. Zongo, 15-44. Paris: L'Harmattan.

Zongo, Mahamadou, ed. 2010b. Les enjeux autour de la diaspora burkinabé. Burkinabé à l'étranger, étrangers au Burkina Faso. Paris: L'Harmattan. 